\title{
Koronární ektazie u pacientky s hypertrofickou kardiomyopatií
}

\section{POPIS PŘÍPADU}

45letá žena byla na naše oddělení přeložena ze spádového interního oddělení nemocnice $\mathrm{v}$ Chebu po (před čtyřmi dny) proběhlé klidové bolesti na hrudi s elevací troponinu. Šlo o pacientku od narození neslyšící na pravé ucho a silně nedoslýchavou na levé ucho. Žena měla rovněž od narození kolobom pravé duhovky, hypermetropický astigmatismus, byla psychomotoricky zpomalená, před lety se podrobila subtotální tyreoidektomii pro nodózní cysticky degenerovanou strumu.

Její 25letá dcera trpí hypertrofickou kardiomyopatii s obstrukcí výtokového traktu levé komory, s gradientem v klidu 40/20 mm Hg, nemá však zájem na dalším vyšetřování. Na EKG naší pacientky byl sinusový rytmus o frekvenci 60, PQ $205 \mathrm{~ms}$, QRS $85 \mathrm{~ms}$, QTc 415, segmenty ST v izoelektrické linii, negativní T aVL, nebyla naplněna voltážní kritéria hypertrofie levé komory (LK). Echokardiografie (obrázek 1M mode, obrázek 2 - transezofageální echokardiografie /TEE/) prokázala hypertrofii stěny LK, nejvýrazněji zadní stěny - $17 \mathrm{~mm}$, septum $15 \mathrm{~mm}$, přední stěna $15 \mathrm{~mm}$ a laterální stěna
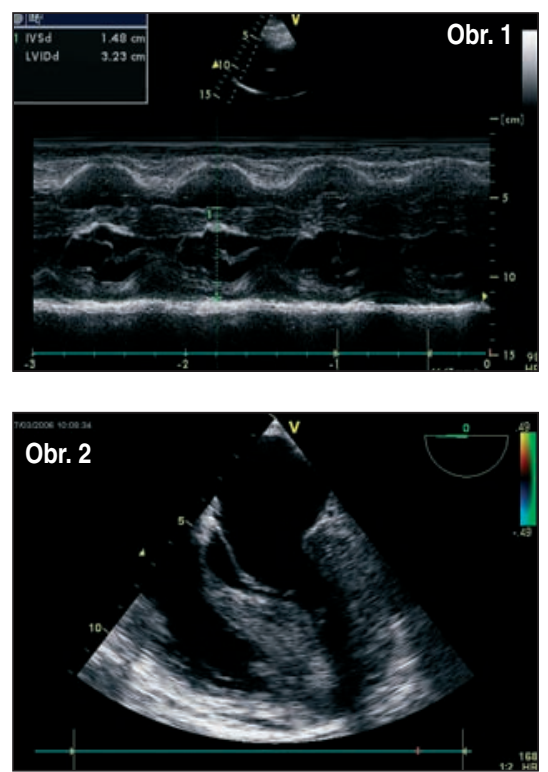

15 mm, myxomatózně změněný přední cíp mitrální chlopně jevil SAM (systolický dopředný pohyb mitrálního aparátu). Při hodnocení regionální kinetiky byla patrna mírná hypokineze inferoapikálně bez omezení globální systolické funkce (ejekční frakce /EF/ dosahovala asi $70 \%$ ). Srdeční oddíly byly normální velikosti, nebyla prokázána chlopenní vada ani vrozená srdeční vada. Při transezofageální
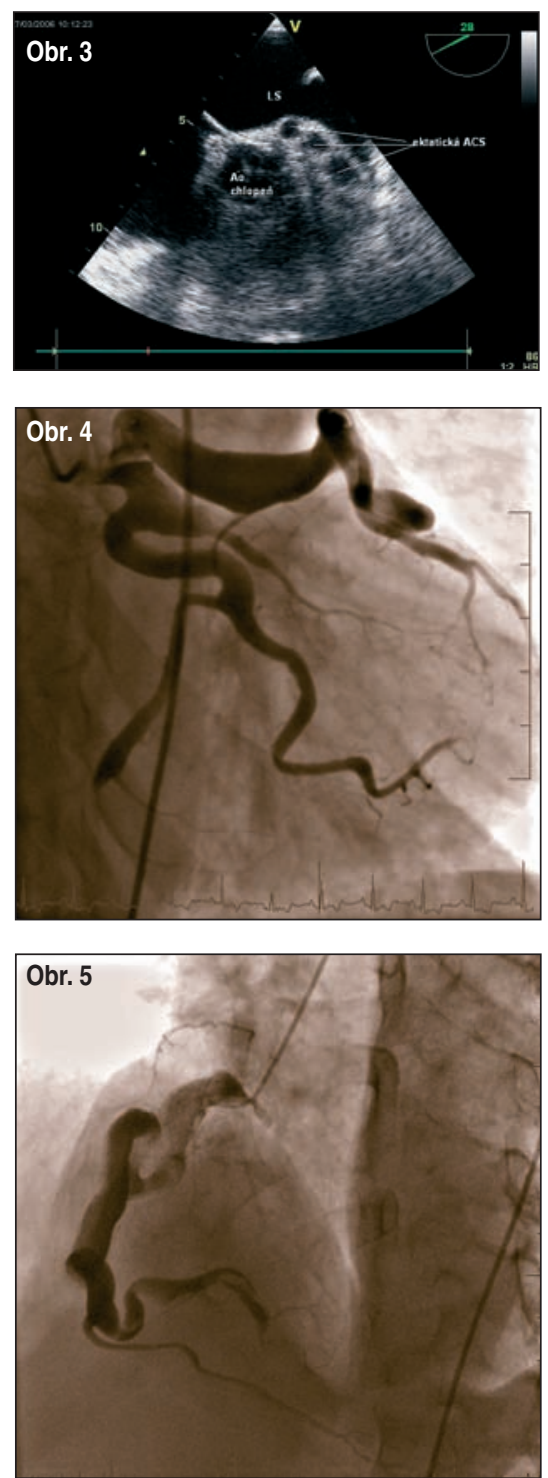

echokardiografii se také zobrazily dilatované proximální části arteria coronaria sinistra /ACS/ (obrázek 3). Selektivní koronarografie prokázala mnohočetné ektazie na ACS (obrázek 4) i ACD /arteria coronaria dextra/ (obrázek 5). Hlavní kmeny věnčitých tepen byly v proximálních částech nerovných kontur a extremně dilatované (až $9 \mathrm{~mm}$ ), periferní části tepen byly relativně tenčí. V celém průběhu byl výrazně zpomalený průtok do periferie, kontrastní látka postupovala pouze $\mathrm{v}$ diastole, v systole nebyl průtok. Na RPLD (ramus posterolateralis dexter) těsně distálně od kř́že byl „stop flow“ s projasněním v kontrastní náplni a patrnou dvojí konturou - šlo bud' o trombus nebo disekci. RPLD se v dalším průběhu plnil pouze fragmentovitě a $\mathrm{v}$ periferii budil dojem hypoplastické tepny. V laboratorních testech nebyly nalezeny signifikantní patologické změny, koncentrace troponinu byly na našem oddělení již negativní. Pacientku jsme propustili s doporučením zahájit p. o. antikoagulační léčbu. Provedená další ambulantní vyšetření (zátěžové testy, kompletní CT-scan) neprokázala další patologické nálezy. Výsledky laboratorní genetické analýzy byly negativní (tedy v rozsahu běžně prováděných testů v České republice).

\section{LITERATURA}

1. Bermudez EP, Palop RL, Lozano I, et al. Coronary ectasia: Prevalence, and clinical and angiographic characteristics. Rev Esp Cardiol 2003;56:473-9.

2. Lam CSP, Ho KT. Coronary artery ectasia: A ten-years experience in a Tertiary Hospital in Singapore. Ann Acad Med Singapure 2004;33: 419-22.

3. Frustraci A, Chimenti C, Pieroni M, et al. Coronary angiodysplasia of epicardial and intramural vessels. Chest 2000;118:1511-3.

4. Swaye PS, Fischer LD, Litwin P, et al. Aneurysmal coronary artery dissease. Circulation 1983;67:134-8.

Michal Padour, Ivo Bernat, Markéta Novotná*, Marcela Škvařilová, Roman Ondrejčák, Beranika Podzemská*, Jaroslav Žák* Oddělení intervenční kardiologie, *Interní oddělení, Karlovarská krajská nemocnice, a. s., Karlovy Vary, Česká republika

Adresa: MUDr. Michal Pad’our, Karlovarská krajská nemocnice, a. s., Bezručova 19, 36066 Karlovy Vary, Česká republika, e-mail: michal.padour@kkn.cz 